J. Dairy Sci. 92:177-188

doi:10.3168/jds.2008-1117

(c) American Dairy Science Association, 2009.

\title{
Evidence for the inhibition of the terminal step of ruminal $\alpha$-linolenic acid biohydrogenation by condensed tannins
}

\author{
R. Khiaosa-Ard, ${ }^{\star}$ S. F. Bryner, ${ }^{*}$ M. R. L. Scheeder, ${ }^{\star} \dagger$ H.-R. Wettstein, ${ }^{\star}$ F. Leiber, ${ }^{*}$ M. Kreuzer, ${ }^{*}$ and C. R. Soliva ${ }^{\star 1}$ \\ *Eidgenössische Technische Hochschule Zurich, Institute of Animal Science, Universitaetstrasse 2, CH-8092 Zurich, Switzerland \\ †SUISAG, Allmend, CH-6204 Sempach, Switzerland
}

\begin{abstract}
Effects of condensed tannins $(\mathrm{CT})$, either via extract or plant-bound, and saponin extract on ruminal biohydrogenation of $\alpha$-linolenic acid (ALA) were investigated in vitro. Grass-clover hay served as basal diet (control). The control hay was supplemented with extracts contributing either CT from Acacia mearnsii $[7.9 \%$ of dietary dry matter (DM)] or saponins from Yucca schidigera (1.1\% of DM). The fourth treatment consisted of dried sainfoin (Onobrychis viciifolia), a CT-containing forage legume, in an amount also providing $7.9 \% \mathrm{CT}$ in dietary DM. All diets were supplemented with linseed oil at a level contributing $60 \%$ of total dietary ALA in all treatments. Diets were incubated for $10 \mathrm{~d}(\mathrm{n}=4)$ in the rumen simulation technique system, using the last $5 \mathrm{~d}$ for statistical evaluation. Fatty acids were analyzed in feed, feed residues, incubation fluid, and its effluent. Data were subjected to ANOVA considering diet and experimental run as main effects. Both CT treatments reduced ruminal fiber and crude protein degradation, and lowered incubation fluid ammonia concentration. Only the CT extract suppressed methane formation and shifted microbial populations toward bacteria at cost of protozoa. The saponin extract remained without clear effects on fermentation characteristics except for increased protozoal counts. The extent of ALA biohydrogenation was $20 \%$ less with the $\mathrm{CT}$ plant, but this probably resulted from reduced organic matter degradability rather than from an inhibition of biohydrogenation. After incubation analysis of incubation fluid effluent and feed residues showed a considerable proportion of the 3 biohydrogenation intermediates, cis-9, trans-11, cis-15 C18:3, trans-11, cis-15 C18:2, and trans-11 C18:1, which did not occur in the initial feeds. Only the CT-extract diet led to a different profile in the effluent compared with the control diet with trans-11 C18:1 being considerably increased at cost of C18:0. This could have been achieved by suppressing protozoa
\end{abstract}

Received February 22, 2008

Accepted September 1, 2008.

${ }^{1}$ Corresponding author: carla.soliva@inw.agrl.ethz.ch and enhancing the bacterial population, thus removing potential microbes involved in biohydrogenation and increasing competition between bacteria involved in biohydrogenation and others. The elevation of trans-11 C18:1 as the precursor of cis-9, trans-11 conjugated linoleic acid formed in body tissue and mammary gland is probably favorable from a human health point of view.

Key words: condensed tannin, $\alpha$-linolenic acid, biohydrogenation

\section{INTRODUCTION}

Certain dietary polyunsaturated fatty acids (PUFA), including n-3 fatty acids (FA) and conjugated linoleic acids (CLA), are considered to be of high importance for human health. It is known that the main form of CLA in ruminant source food, rumenic acid (cis-9, trans-11 C18:2), can be synthesized in the animal's tissues using vaccenic acid (trans-11 C18:1) from the rumen as a precursor or can be directly formed during microbial hydrogenation of PUFA in the rumen; however, the latter pathway contributes only minimal amounts to the total CLA in ruminant tissues (Griinari and Bauman, 1999). In grass-fed ruminants, $\alpha$-linolenic acid (ALA; cis-9, cis-12, cis-15 C18:3) is the major unsaturated dietary FA supplied and is known to be the precursor of all long-chain n-3 FA. The elevation of desired PUFA in ruminant source foods therefore requires an increased ruminal bypass of ALA without being modified through microbial biohydrogenation. By contrast, for the generation of CLA, biohydrogenation of C18 PUFA is required.

One main measure to increase beneficial PUFA in animal source food is the use of high-forage diets. However, comparison of different studies based on such feeding systems (e.g., Leiber et al., 2005) reveals that differing forage characteristics as well as differing forage proportions in the diet influence the FA profile of milk. The possible causes for these influences are manifold and not yet fully understood, but it is clear that ruminal lipid metabolism plays a major role. The effect of any feed source on the FA profile of animal 
source foods therefore depends on complex interactions between plant FA, other plant compounds, and ruminal microorganisms.

Bacteria are largely responsible for the biohydrogenation of unsaturated FA in the rumen, although no single species of ruminal bacteria catalyzes the complete biohydrogenation sequence (Martin and Jenkins, 2002). Recent evidence, however, is given for the involvement of the protozoa in ruminal biohydrogenation, either directly or via attached bacteria (Boeckaert et al., 2007). In the in vitro study of Martin and Jenkins (2002), changes in the ruminal environment including $\mathrm{pH}$, amount and type of substrate, and incubation liquid dilution rate caused variations in microbial activity that corresponded to alterations in biohydrogenation end products found. This indicates that other treatments affecting microbial populations might influence biohydrogenation as well.

The so-called plant secondary compounds are known to have pronounced and significantly differing effects on ruminal microbes. Two groups of plant secondary compounds frequently found in the plant domain are tannins and saponins. Condensed tannins (CT) have been reported to modify ruminal fermentation by inhibiting ammonia and methane production (Carulla et al., 2005) partially by their ability to form complexes with dietary protein and fiber. Concerning lipid metabolism, tannins were shown to inhibit Butyrivibrio fibrisolvens (Jones et al., 1994), one of the bacterial species known to be a major microbial species involved in ruminal biohydrogenation. Saponins are known to have strong anti-protozoal activity, which is often associated with increased numbers of bacteria. Decimating protozoa, which are bacterial predators, therefore results in a decrease in ammonia-nitrogen (e.g., Santoso et al., 2007). Thus, an influence of CT and saponins on ruminal lipid metabolism and, therefore, FA profile of ruminant food sources could be expected.

To our knowledge, there are only few studies aiming at the effects of plant secondary compounds on biohydrogenation. Durmic et al. (2007) investigated Australian plants with the potential to affect microbes and ruminal biohydrogenation processes, but the respective plant secondary compounds responsible were not identified. Turner et al. (2005) reported the effect of a CTcontaining plant on milk FA profile. Therefore, we tested the hypothesis that these plant secondary compounds are active in altering the ALA biohydrogenation at one or more steps via their effects on the microbial population. Both CT and saponins are commercially available as extracts in various forms. However, chemical composition and integration within the natural matrix may affect modes of action or efficiency in modifying ruminal biohydrogenation. For that reason, apart from a CT and a saponin extract, CT-containing forage was tested. Thereby, the extract was added at the same level of $\mathrm{CT}$ as was provided by the CT-forage. To be able to get information on possible causes of biohydrogenation effects, various fermentation traits were followed.

\section{MATERIALS AND METHODS}

\section{Experimental Diets}

Four experimental treatments (Table 1) were investigated for their effects on ruminal biohydrogenation of ALA present in the plant lipids as well as supplemented via linseed oil. The first diet $(\mathbf{C H})$ consisted of grassclover hay only and served as control being assumed to be low in plant secondary compounds. It consisted of $51 \%$ ryegrass (98\% Lolium perenne), $43 \%$ clover ( $72 \%$ Trifolium repens, $28 \%$ Trifolium pratense), and 6\% herbs (mainly Taraxacum officinale). The second diet (TF) consisted of dried sainfoin (Onobrychis viciifolia) naturally containing $8.12 \%$ condensed tannins in plant DM. The third diet (TH) consisted of control hay and tannin extract of Acacia mearnsii (Weibull Black, Tanac S.A., Montenegro, Brazil). The extract originated from the same batch as used in the study of Carulla et al. (2005) and contained $61.5 \%$ CT in DM as analyzed. The CT supplementation level was kept at the same daily amount of CT $(1.12 \mathrm{~g} / \mathrm{d})$ as provided with sainfoin in diet TF. The fourth $\operatorname{diet}(\mathbf{S H})$ consisted of the control hay, supplemented with an extract of Yucca schidigera (30\% saponin (here sarsaponin) in DM according to the producer's statement; Deodorase, Alltech Inc., Nicholasville, KY). The saponin level in the $\mathrm{SH}$ diet was chosen to amount to $1.1 \%$ of DM (i.e., $0.153 \mathrm{~g}$ of saponin supply per day), corresponding to the highest dose of saponins investigated in Hess et al. (2003). Linseed oil was added in an amount equivalent to $3 \%$ of control DM (0.39 g per day and fermenter) to all 4 experimental diets to increase substrate for ruminal biohydrogenation. The forages used supplied additional lipids, which contributed $40 \%$ of total dietary ALA (Table 1). Total dietary DM supply to the fermenter slightly differed among the 4 diets because the DM amount of dietary nonsecondary plant compound was always kept constant.

\section{Rusitec Experiment}

The in vitro system used in the present study was an 8-fermenter Rusitec as described by Soliva and Hess (2007). The 4 treatments were tested in 2 experimental runs with 2 replicates per treatment in each run $(n=4)$. Experimental runs lasted for $10 \mathrm{~d}$ each, with the final 5 d serving for data collection. It was tested by exclud- 
Table 1. Supply of dietary ingredients and nutrients as well as fatty acid composition of the experimental diets

\begin{tabular}{|c|c|c|c|c|}
\hline \multirow[b]{2}{*}{ Item } & \multicolumn{4}{|c|}{ Dietary treatment ${ }^{1}$} \\
\hline & $\mathrm{CH}$ & $\mathrm{TF}$ & $\mathrm{TH}$ & $\mathrm{SH}$ \\
\hline \multicolumn{5}{|l|}{ Feed supply per fermenter. ${ }^{2} \mathrm{~g}$ of $\mathrm{DM} / \mathrm{d}$} \\
\hline Grass-clover hay & 12.7 & & 12.0 & 12.7 \\
\hline Dried sainfoin (Onobrychis viciifolia) & & 13.8 & & \\
\hline Tannin-rich extract of Acacia mearnsii & & & 1.81 & \\
\hline Saponin-rich extract of Yucca schidigera & & & & 0.51 \\
\hline Linseed oil & 0.39 & 0.39 & 0.39 & 0.39 \\
\hline Total & 13.1 & 14.2 & 14.2 & 13.6 \\
\hline Material other than tannin and saponin & 13.1 & 13.1 & 13.1 & 13.4 \\
\hline \multicolumn{5}{|l|}{ Analyzed nutrient composition, ${ }^{3} \%$ of DM } \\
\hline $\mathrm{OM}$ & 81.6 & 85.5 & 83.5 & 82.2 \\
\hline NDF & 31.7 & 22.5 & 27.6 & 30.5 \\
\hline Non-NDF carbohydrates ${ }^{4}$ & 23.9 & 36.0 & 32.9 & 26.8 \\
\hline $\mathrm{CP}$ & 20.9 & 22.2 & 18.4 & 20.1 \\
\hline Ether extract & 5.09 & 4.77 & 4.60 & 4.90 \\
\hline Condensed tannins added & - & 7.89 & 7.89 & - \\
\hline Saponins added ${ }^{5}$ & - & - & - & 1.12 \\
\hline \multicolumn{5}{|l|}{ Supply of C18:3 cis- 9 , cis- 12 , cis- $15,{ }^{6} \mathrm{mg} / \mathrm{d}$} \\
\hline Total & 353 & 357 & 345 & 353 \\
\hline From oil & 211 & 211 & 211 & 211 \\
\hline From forage & 142 & 146 & 134 & 142 \\
\hline \multicolumn{5}{|c|}{ Dietary C18 fatty acid composition, $\%$ of total FA } \\
\hline C18:0 & 3.45 & 3.69 & 3.46 & 3.45 \\
\hline $\mathrm{C} 18: 1$ cis -9 & 11.4 & 11.7 & 11.6 & 11.4 \\
\hline $\mathrm{C} 18: 2$ cis-9, cis-12 & 15.9 & 15.7 & 15.9 & 15.9 \\
\hline $\mathrm{C} 18: 3$ cis- 6 , cis-9, cis- 12 & 0.170 & 0.138 & 0.165 & 0.170 \\
\hline $\mathrm{C} 18: 3$ cis- 9, cis- 12, cis- 15 & 52.8 & 52.8 & 52.8 & 52.8 \\
\hline \multicolumn{5}{|c|}{$\begin{array}{l}{ }^{1} \mathrm{CH}=\text { control; } \mathrm{TF}=\text { tannin-containing forage (sainfoin); } \mathrm{TH}=\text { tannin extract; and } \mathrm{SH}=\text { saponin extract. } \\
{ }^{2} \text { Additionally, } 1 \mathrm{~g} / \mathrm{d} \text { of an inert carrier was supplemented with the linseed oil but is not itemized here. } \\
{ }^{3} \text { The values accounting with including linseed oil. } \\
{ }^{4} \text { Calculated as } \mathrm{OM} \text { minus NDF, } \mathrm{CP} \text {, and ether extract. } \\
{ }^{5} \text { Calculated from producer statement. }\end{array}$} \\
\hline
\end{tabular}

ing the presence of day $\times$ treatment effects with the example of the VFA that an adaptation period for the ruminal microbes lasting for $5 \mathrm{~d}$ had been sufficiently long. Each of the 1-l fermenters was initially filled with $900 \mathrm{~mL}$ of ruminal fluid strained through 4 layers of medicinal gauze $(1,000 \mu \mathrm{m}$ pore size, Type 17 ; MedPro Novamed AG, Flawil, Switzerland) and $100 \mathrm{~mL}$ of McDougall buffer according to the description of Soliva and Hess (2007). Ruminal fluid was obtained from a rumen-fistulated lactating Brown Swiss cow fed a diet consisting of hay and concentrate in a ratio of $1.5: 1$. The cow was housed according to the Swiss guidelines for animal welfare. The experimental diets were supplied in nylon bags $(70 \times 140 \mathrm{~mm})$, with a pore size of 100 $\mu \mathrm{m}$ (Soliva and Hess, 2007). On the first day of each of the 2 experimental runs, 2 nylon bags were placed into each fermenter. One bag contained solid ruminal content from the donor cow to ease the establishment of favorable fermentation conditions, whereas the other bag was filled with the experimental diet. After $24 \mathrm{~h}$ of incubation, the bag containing the ruminal solids was replaced with a nylon bag containing the respective experimental diet. Prior to incubation, dietary forages were ground in a laboratory mill to pass a $5-\mathrm{mm}$ sieve and then mixed with the respective extracts. Shortly before filling into the nylon bags, $0.39 \mathrm{~g}$ of linseed oil that had been adsorbed onto $1 \mathrm{~g}$ of an inert carrier substance (Isolute HM-N, International Sorbent Technology Ltd., Hengoed Mid Glamorgan, UK) was added to the diets. Therewith, the elution of the oil from the nylon bag was avoided. Each bag was incubated for 48 $\mathrm{h}$, then taken out and rinsed with $50 \mathrm{~mL}$ of prewarmed McDougall buffer while squeezing the bag above the open fermenter to reduce microbial cell losses. Afterward, feed residues were stored at $-20^{\circ} \mathrm{C}$ until analyses. Anaerobic conditions were reestablished in the fermenters by flushing the headspace of the fermenters for 3 min with gaseous nitrogen after feeding. During the final $5 \mathrm{~d}$ of each run, daily samples of incubation fluid for fermentation trait analyses were collected $3 \mathrm{~h}$ before feed bags were exchanged. Liquid samples for FA analyses were taken daily from incubation fluid effluent $(20 \%$ 
of total effluent collected per fermenter and day), frozen at $-20^{\circ} \mathrm{C}$, and pooled before being analyzed. With a buffer flow rate of approximately $500 \mathrm{~mL} / \mathrm{d}$, fatty acid outflow of the fermenters stayed approximately constant from d 5 onward. On the last day when no new feed was added to the system, the incubation fluid therefore theoretically corresponded to the one bag with fatty acids, the content of which was collected for later FA analysis and to calculate daily FA recovery. Feed samples and residues, which were pooled across the last $5 \mathrm{~d}$ of each experimental run, were ground to pass a $0.5-\mathrm{mm}$ sieve. These samples had been collected especially to enable the calculation of the extent of FA biohydrogenation by opposing dietary FA supply to FA recovered in feed residues and incubation fluid, which in total reflects the daily amount of FA present in the fermenter once its content was adapted to the diet. For control, the calculation of recoveries was also made with the effluent pooled across d 6 to 10 . This resulted in quite similar, though not identical, values and differences among treatments were similarly significant or nonsignificant.

\section{Analysis of Chemical Composition of Feeds and Feed Residues and Standard Fermentation Traits}

Contents of DM, total ash, and ether extract in feed and feed residues were determined according to standard methods described in AOAC (1997). Contents of NDF were analyzed with a Fibertec 1020 system (Tecator; Höganäs, Sweden) with the use of $\alpha$-amylase (Termamyl 120L, type S; Novo Nodirsk A/S, Bagsværd, Denmark) as described by Soliva and Hess (2007). Sodium sulfite was only added in analysis of NDF in feeds and residues containing tannins as recommended by Robbins et al. (1987). A C/N analyzer (Type FP2000, Leco Corporation, St. Joseph, MI) was used to determine $\mathrm{N}$, with $\mathrm{CP}$ being calculated as $\mathrm{N} \times 6.25$. The CT contents of CT extract and sainfoin had been determined by the butanol/HCl procedure according to Terrill et al. (1992).

After collection, incubation fluid samples were immediately analyzed with a potentiometer (model 173, Metrom, Herisau, Switzerland) equipped with respective electrodes for redox potential, $\mathrm{pH}$, and ammonia. Total counts of ciliate protozoa and bacteria present in incubation fluid were determined using 0.1- and 0.02-mm depth Bürker counting chambers (Blau Brand, Wertheim, Germany). Prior to counting, microbial samples were fixed with Hayem solution $(\mathrm{mg} / \mathrm{mL}$; $\left.\mathrm{HgCl}_{2}, 2.5 ; \mathrm{Na}_{2} \mathrm{SO}_{4}, 25 ; \mathrm{NaCl}, 5.0\right)$. The VFA analyses were performed on a HPLC (System Hitachi Lachrom, Merck, Tokyo, Japan) according to the method of Ehrlich et al. (1981). The complete fermentation gases were collected daily in gas-tight 8-L bags (TECOBAG, PETP/AL/PE-12/12/75 quality; Tesseraux Container GmbH, Bürstadt, Germany) and were analyzed for their volume by the corresponding water replacement. Concentrations of methane, hydrogen, and carbon dioxide were determined with a gas chromatograph (model 5890 Series II, Hewlett Packard, Avondale, PA) equipped with a thermal conductivity and a flame ionization detector. The column used to detect fermentation gases was Carboxen-1000 (15' × 1/8' SS, mesh size 60/80; Fluka Chemie AG, Buchs, Switzerland).

\section{Fatty Acid Analysis of Feeds, Feed Residues, Incubation Fluid, and Effluent}

The lipids present in diet ingredients and feed residues, except linseed oil, were first extracted by accelerated solvent extraction (ASE 200, Dionex Corporation, Sunnyvale, CA) with hexane:propan-2-ol (3:2 vol/vol). Subsequently, an internal standard $(1 \mathrm{mg}$ of $\mathrm{C} 21: 0 / \mathrm{mL}$ of dichloromethane; Fluka, Steinheim, Germany) was added, the solvent was evaporated in a stream of nitrogen, and the extract was collected with $2 \mathrm{~mL}$ of dichloromethane. An amount of $10 \mathrm{~mL}$ of distilled water was then added to $1 \mathrm{~mL}$ of the extract. For liquid samples, 10 $\mathrm{mL}$ of incubation fluid and pooled effluent were mixed with $1 \mathrm{~mL}$ of the internal standard C21:0. Afterwards, $11 \mathrm{~mL}$ of the mixtures were hydrolyzed by adding 2.5 $\mathrm{mL}$ of $10 \mathrm{M} \mathrm{NaOH}$, heated for $40 \mathrm{~min}$ at $90^{\circ} \mathrm{C}$ and then cooled to ambient temperature. The solution was acidified with $4 \mathrm{~mL}$ of $6 \mathrm{M} \mathrm{HCl}$ to release the free FA from soaps formed during hydrolysis. The free FA were extracted by adding propan-2-ol and cyclohexane in amounts appropriate to get final proportions of propan2-ol, cyclohexane, and water of 8:10:11 ( $\mathrm{vol} / \mathrm{vol} / \mathrm{vol}$ ) according to the nonchlorinated extraction of Smedes (1999). After the second extraction step with propan-2ol and cyclohexane $(1.3: 10 \mathrm{vol} / \mathrm{vol})$, the organic solvent was evaporated using a Rota-Vap (Heidolph VV2000, Heidolph Elektro \& Co., KG, Kelheim, Germany), and the FA were recovered by treating samples 2 times with $1 \mathrm{~mL}$ of chloroform. The complete recovery of the lipids by this extraction procedure was confirmed by tests carried out in advance (data not shown). The methylation was performed after evaporation of the chloroform in a stream of $\mathrm{N}_{2}$ at $40^{\circ} \mathrm{C}$. Subsequently $1 \mathrm{~mL}$ toluene:methanol mixture $(1: 2, \mathrm{vol} / \mathrm{vol})$ and trimethylsilyl-diazomethane (TMS-DAM, $2 M$ in hexane) given in excess $(80$ to $120 \mu \mathrm{L}$ ) were added to methylate the FA as outlined by Aldai et al. (2005). Excess solvent and diazomethane were removed and the FA methylesters were recovered in $200 \mu \mathrm{L}$ of hexane for purification by thin layer chromatography as described by Kramer and Zhou (2001). The FA present in all types of extracts 
were then separated by gas chromatography (model HP 6890, Hewlett-Packard, Palo Alto, CA) equipped with a flame-ionization detector in 2 separate runs using a 30 $\mathrm{m} \times 0.32 \mathrm{~mm}$ Supelcowax-10 (Supelco Inc., Bellefonte, $\mathrm{PA}$ ) and a $200 \mathrm{~m} \times 0.25 \mathrm{~mm}$ CP7421 capillary column (Varian Inc., Lake Forest, CA). In detail, for the first run the injector and detector temperatures were 260 and $250^{\circ} \mathrm{C}$, respectively. The temperature program was carried out with an initial temperature of $160^{\circ} \mathrm{C}$ held for $0.5 \mathrm{~min}$. The 3 -step temperature ramps consisted of increasing at $20^{\circ} \mathrm{C} / \mathrm{min}$ from 160 to $190^{\circ} \mathrm{C}$, at $7^{\circ} \mathrm{C} /$ min from 190 to $230{ }^{\circ} \mathrm{C}$ then held for $5.3 \mathrm{~min}$ and at $20^{\circ} \mathrm{C} / \mathrm{min}$ from 230 to $250^{\circ} \mathrm{C}$ as the final temperature held for $6 \mathrm{~min}$. Hydrogen was used as a carrier gas with flow rate at $2.2 \mathrm{~mL} / \mathrm{min}$. A mixed FAME standard (Supelco 37 component, Supelco Inc.) was used for the identification of the fatty acids. The second run with the latter column was necessary for a detailed separation of the $\mathrm{C} 18: 1 \mathrm{FA}$ isomers. The injector temperature was $270^{\circ} \mathrm{C}$. The running started at $181^{\circ} \mathrm{C}$ for $60 \mathrm{~min}$. The temperature was increased at a rate of $5^{\circ} \mathrm{C} / \mathrm{min}$ from 181 to $230^{\circ} \mathrm{C}$, held for $32 \mathrm{~min}$, and then at $5^{\circ} \mathrm{C} /$ min until reaching a final temperature of $250^{\circ} \mathrm{C}$, which was held for $12 \mathrm{~min}$. Hydrogen flow was $1.7 \mathrm{~mL} / \mathrm{min}$ at start and $1.3 \mathrm{~mL} / \mathrm{min}$ after $60 \mathrm{~min}$ of run.

\section{Calculations and Statistical Analysis}

Apparent biohydrogenation and the proportions of the biohydrogenation intermediates were quantitatively estimated from supply and recovery of the amounts of the C18 FA following Li and Meng (2006). Data to quantify biohydrogenation were adjusted per fermenter by the apparent recovery rate of total FA in feed residue and incubation fluid. Means of d 6 to 10 were used for each fermenter and experimental run to evaluate the dietary effects by analyses of variance. For this purpose the GLM procedure (SAS Institute Inc., Cary, NC) was applied, with diet and experimental run being considered as sources of variation. The comparisons among means were performed with Tukey's method.

\section{RESULTS}

The diets had a similar nutrient composition except that $\mathrm{CP}$ was less in diet TH partly due to a dilution by CT extract and NDF was slightly less in sainfoin hay than in the grass-clover hay (Table 1). As intended, $84 \%$ on average of total FA in the diet were composed of C18 FA. In detail, ALA (cis-9, cis-12, cis-15 C18:3) was the major FA accounting for $53 \%$, whereas linoleic acid (cis-9, cis-12 C18:2), oleic acid (cis-9 C18:1), and stearic acid (C18:0) on average made up 16, 12, and $3.5 \%$, respectively. Proportionate to total C18 FA,
ALA, linoleic acid, oleic acid, and stearic acid made up $64,19,13$, and $4 \%$, respectively.

\section{Effects on Ruminal Fermentation}

Incubation fluid $\mathrm{pH}$ did not differ among treatments (Table 2). Compared with the control, in the CT containing diets ammonia concentrations were reduced $(P$ $<0.05$ ) by 70 and $42 \%$ with $\mathrm{TH}$ and TF, respectively, whereas the saponin extract showed no effect. In the presence of the CT extract, ciliate protozoal counts were less $(P<0.05)$ than in the other treatments whereas bacterial counts increased $(P<0.05)$. By contrast, the saponin extract enhanced $(P<0.05)$ protozoal counts. No significant difference was detected in total VFA concentration ranging from 106 to $113 \mathrm{mM}$. However, lesser acetate $(\mathrm{TH})$ and greater propionate proportions ( $\mathrm{TF}$ and $\mathrm{TH}$ ) were observed, resulting in lesser acetate to propionate ratios in the $2 \mathrm{CT}$-containing diets relative to $\mathrm{CH}$ and $\mathrm{SH}$. Regarding fermentation gases produced during $24 \mathrm{~h}$ of incubation, $\mathrm{TH}$ appeared to have reduced fermentative activity compared with the other diets (significantly different to some other treatments in total gas, carbon dioxide, and methane). The CTextract suppressed methane per unit of fermented OM $(P<0.05)$ and hydrogen release $(P<0.1)$ compared with the other diets. The greatest methane values in relation to apparently fermented NDF were generated by diet TF. Both CT-containing diets decreased $(P<$ $0.05)$ the nutrient disappearance, equivalent to apparent ruminal degradation, with reductions of up to 19 and 50 on average for $\mathrm{OM}$ and $\mathrm{CP}$, respectively, relative to $\mathrm{CH}$. Concerning non-NDF carbohydrates, such a decline was only found with $\mathrm{TH}$, whereas the reduction in NDF disappearance was even larger. The latter values are, however, not very reliable considering the known interactions with tannins. The saponin extract had no such effect. Moreover, the apparent disappearance of ether extract was found to be lowest in TF, accounting for only $16 \%$, whereas this value was greater in TH but still less than in $\mathrm{CH}$ and $\mathrm{SH}(P<0.05)$.

\section{Effects on Fatty Acid Profile and Biohydrogenation}

In the lipids present in the effluent, the initial isomerization product from ALA biohydrogenation, cis-9, trans-11, cis-15 C18:3, did not significantly differ as a proportion of total C18 FA among treatments as was also true for the product of the second step (trans-11, cis-15 C18:2; Table 3). By contrast, the product from the third step (i.e., trans-11 C18:1) was greatest in proportion $(P<0.05)$ with the $\mathrm{CT}$ extract (diet TH), being 3 to 4 times greater than in the other treatments. In addition, other trans-monoene isomers were found to 
Table 2. Effect of dietary treatments on fermentation characteristics (averages of d 6 to 10$)^{1}$

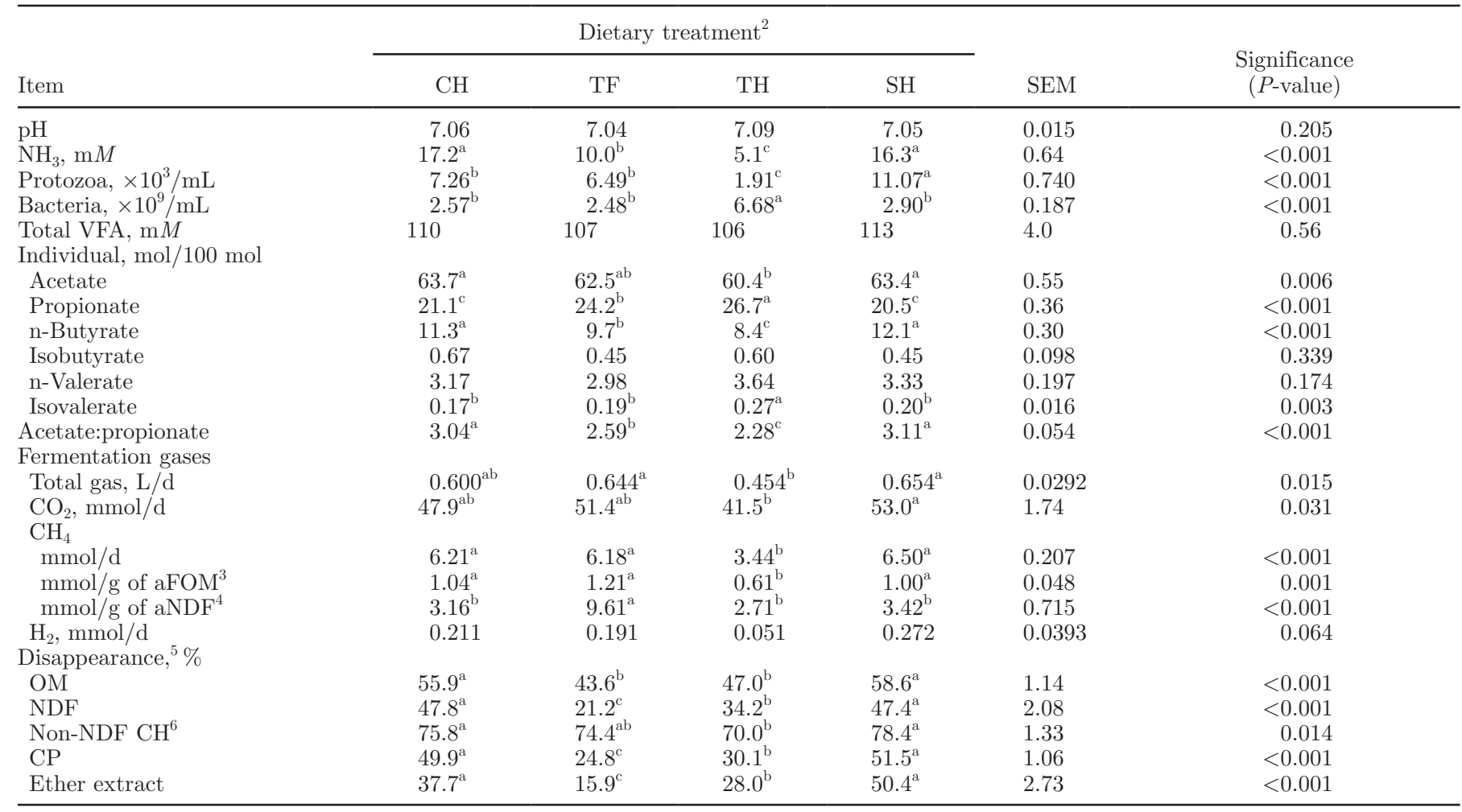

${ }^{\mathrm{a}-\mathrm{c}}$ Mean values within the same row sharing no common superscript are significantly different $(P<0.05)$.

${ }^{1}$ Means by treatment, $\mathrm{n}=4$.

${ }^{2} \mathrm{CH}=$ control; $\mathrm{TF}=$ tannin-containing forage (sainfoin); $\mathrm{TH}=$ tannin extract; and $\mathrm{SH}=$ saponin extract.

${ }^{3}$ Apparently fermented OM.

${ }^{4}$ Apparently fermented NDF.

${ }^{5}$ Apparent disappearance $=[($ supply - residue $) /$ supply $] \times 100$.

${ }^{6}$ Non-NDF carbohydrates calculated as OM minus NDF, CP, and ether extract.

be 2 to 3 times greater $(P<0.05)$ in $\mathrm{TH}$ than in the other treatments, whereas varying results were detected in cis-monoenes. In compensation, stearic acid proportion was less $(P<0.05)$ with $\mathrm{TH}$ by on average $47 \%$ relative to $\mathrm{CH}$. The main initial isomerization product of linoleic acid, CLA, did not significantly differ among dietary treatments. There was also no significant treatment effect on linoleic acid and ALA proportions of total C18 FA, whereas $\gamma$-linolenic acid (cis-6, cis-9, cis$12 \mathrm{C} 18: 3)$ was elevated $(P<0.05)$ in treatment $\mathrm{TH}$. The profile of FA in the incubation fluid taken from the respective fermenters after $10 \mathrm{~d}$ of incubation (data not shown) showed a similar trend in being affected by the treatments.

In the lipids of the feed residues, treatment effects on the proportions of the $\mathrm{C} 18 \mathrm{FA}$ were found to be similar in type but smaller in extent than in the effluent (Table 4). Accordingly, stearic acid was less $(P<$ $0.05)$ by $24.3,31.5$, and $40.2 \%$ with $\mathrm{TH}$ in relation to $\mathrm{TF}, \mathrm{CH}$, and $\mathrm{SH}$, respectively, whereas trans-11 C18:1 proportion with $\mathrm{TH}$ again was greatest. Some isomers of trans- and cis-C18:1 differed among treatments, whereas the saponin-containing diet expressed the greatest $(P<0.05)$ level in most of these FA proportions. No difference was noted for proportions of most of dienoic and trienoic acids, including CLA isomers, but ALA proportion was found greatest $(P<0.05)$ in the sainfoin residue.

On average the FA recovery in feed residues and incubation fluid (data not shown) was as high as $94 \%$. Biohydrogenation of unsaturated C18 FA, mathematically adjusted by the total FA recovery rates for each fermenter, was at a similar level for all diets except TF, where a lesser extent of biohydrogenation was found (Table 5). This was valid for both ALA and linoleic acid $(-20$ and $-21 \%$ relative to $\mathrm{CH})$. Across all diets, biohydrogenation was greatest for ALA (up to 70\%), less for linoleic acid (up to 50\%), and even less for oleic acid (up to 22\%). The low apparent biohydrogenation of ALA in treatment TF resulted in the highest $(P<$ 
Table 3. Effect of dietary treatments on the total C18 fatty acid recovered per day and the C18 fatty acid profile (\% of total C18 fatty acids) of incubation fluid effluent (averages of $\mathrm{d} 6$ to 10)

\begin{tabular}{|c|c|c|c|c|c|c|}
\hline \multirow[b]{2}{*}{ Item } & \multicolumn{4}{|c|}{ Dietary treatment ${ }^{1}$} & \multirow[b]{2}{*}{ SEM } & \multirow{2}{*}{$\begin{array}{l}\text { Significance } \\
(P \text {-value })\end{array}$} \\
\hline & $\mathrm{CH}$ & $\mathrm{TF}$ & $\mathrm{TH}$ & $\mathrm{SH}$ & & \\
\hline \multicolumn{7}{|l|}{$\mathrm{C} 18: 1$ trans } \\
\hline 4 & $0.122^{\mathrm{ab}}$ & $0.088^{\mathrm{c}}$ & $0.145^{\mathrm{a}}$ & $0.108^{\mathrm{bc}}$ & 0.0078 & 0.002 \\
\hline 5 & $0.088^{\mathrm{b}}$ & $0.077^{\mathrm{b}}$ & $0.130^{\mathrm{a}}$ & $0.075^{\mathrm{b}}$ & 0.0078 & 0.001 \\
\hline 10 & $0.855^{\mathrm{ab}}$ & $0.580^{\mathrm{b}}$ & $1.056^{\mathrm{a}}$ & $0.901^{\mathrm{ab}}$ & 0.0838 & 0.014 \\
\hline 11 & $11.7^{\mathrm{b}}$ & $7.6^{\mathrm{b}}$ & $30.7^{\mathrm{a}}$ & $10.9^{\mathrm{b}}$ & 0.95 & $<0.001$ \\
\hline 12 & $0.7658^{\mathrm{b}}$ & $0.563^{\mathrm{c}}$ & $0.989^{\mathrm{a}}$ & $0.723^{\mathrm{bc}}$ & 0.0413 & 0.001 \\
\hline $13+14$ and $(6+7+8$ cis $)$ & 2.76 & 2.25 & 2.14 & 2.84 & 0.167 & 0.027 \\
\hline 16 & $1.34^{\mathrm{a}}$ & $1.10^{\mathrm{ab}}$ & $0.96^{\mathrm{b}}$ & $1.42^{\mathrm{a}}$ & 0.085 & 0.010 \\
\hline \multicolumn{7}{|l|}{$\mathrm{C} 18: 1$ cis } \\
\hline 9 and (15 trans) & 7.55 & 9.51 & 9.18 & 7.82 & 0.533 & 0.061 \\
\hline 15 & $0.386^{\mathrm{a}}$ & $0.283^{\mathrm{b}}$ & $0.220^{\mathrm{b}}$ & $0.423^{\mathrm{a}}$ & 0.0238 & $<0.001$ \\
\hline 16 & $0.185^{\mathrm{b}}$ & $0.149^{\mathrm{b}}$ & $0.275^{\mathrm{a}}$ & $0.169^{\mathrm{b}}$ & 0.0126 & $<0.001$ \\
\hline \multicolumn{7}{|l|}{ C18:2 nonconjugated } \\
\hline cis -9, cis -12 & 4.78 & 5.54 & 4.74 & 5.11 & 0.215 & 0.081 \\
\hline trans- 11, cis-15 & 5.80 & 5.08 & 5.63 & 6.08 & 0.352 & 0.289 \\
\hline C18:2 conjugated & 1.83 & 2.43 & 2.22 & 1.66 & 0.218 & 0.101 \\
\hline \multicolumn{7}{|l|}{ C18:3 } \\
\hline cis-6, cis-9, cis-12 & $0.155^{\mathrm{b}}$ & $0.107^{\mathrm{b}}$ & $0.338^{\mathrm{a}}$ & $0.140^{\mathrm{b}}$ & 0.0119 & $<0.001$ \\
\hline cis- 9, cis -12, cis -15 & 4.32 & 6.81 & 4.76 & 5.65 & 0.768 & 0.168 \\
\hline cis -9, trans -11, cis -15 & 4.19 & 6.78 & 5.48 & 3.63 & 1.03 & 0.196 \\
\hline
\end{tabular}

${ }^{\mathrm{a}-\mathrm{c}}$ Mean values within the same row sharing no common superscript are significantly different $(P<0.05)$.

${ }^{1} \mathrm{CH}=$ control; $\mathrm{TF}=$ tannin-containing forage (sainfoin); $\mathrm{TH}=$ tannin extract; and $\mathrm{SH}=$ saponin extract.

0.05) proportion of ALA in the C18 FA recovered and, consequently, in a low C18:0 proportion (Figure 1). In $\mathrm{TH}$, by contrast, ALA disappearance was similarly high as in $\mathrm{CH}$ and $\mathrm{SH}$, but the profile of the intermediate and end product of ALA biohydrogenation was different (Figure 1). In particular, trans-11 C18:1 was affected as it accumulated $(P<0.05)$ with $\mathrm{TH}$ at cost of the end product $\mathrm{C} 18: 0$. As a result $\mathrm{C} 18: 0$ made up the least proportion of the $\mathrm{C} 18 \mathrm{FA}$ recovered in $\mathrm{TH}$ (significant compared with $\mathrm{CH}$ and $\mathrm{SH}$ ).

\section{DISCUSSION}

Transfer efficiency of n-3 FA from feed to milk and meat is known to be much less in ruminants than in nonruminants. This is due to ruminal biohydrogenation whose extent decides the amount of dietary ALA being recovered in animal source food. However, ALA biohydrogenation also provides precursors for CLA, another group of FA considered beneficial to human health. In the present study, effects of CT and saponins on biohydrogenation were investigated because these classes of substances are known for their ability to influence ruminal microbes and their activity. Thereby these substances act directly by being toxic to the microbes or indirectly by forming complexes with nitrogenous compounds and other nutrients, which therefore are not being available to the microbes any more. The in vitro system used was considered to be appropriate to accurately estimate the proportion of C18 PUFA converted into their saturated end product. Values were comparable with in vivo conversion when the considerations for appropriate biohydrogenation simulation (e.g., amount of C18 PUFA supply and fermentation substrate as well as incubation $\mathrm{pH}$ ) as suggested by Fievez et al. (2007) were taken into account.

\section{Effects of CT and Saponins on Ruminal Microbes and Fermentation}

In the present study, 2 different sources of CT had been used, an extract from Acacia mearnsii (TH), and native, CT-containing sainfoin (TF). Although both diets provided the amount of $\mathrm{CT}$, only $\mathrm{TH}$ had major effects on the rumen microbial populations (i.e., a decline in protozoal counts by $74 \%$ and a compensatory 
Table 4. Effect of dietary treatments on the C18 fatty acid profile (\% of total C18 fatty acids) of feed residues (averages of d 6 to 10$)$ and the total $\mathrm{C} 18$ fatty acid recovered in feed residues per day

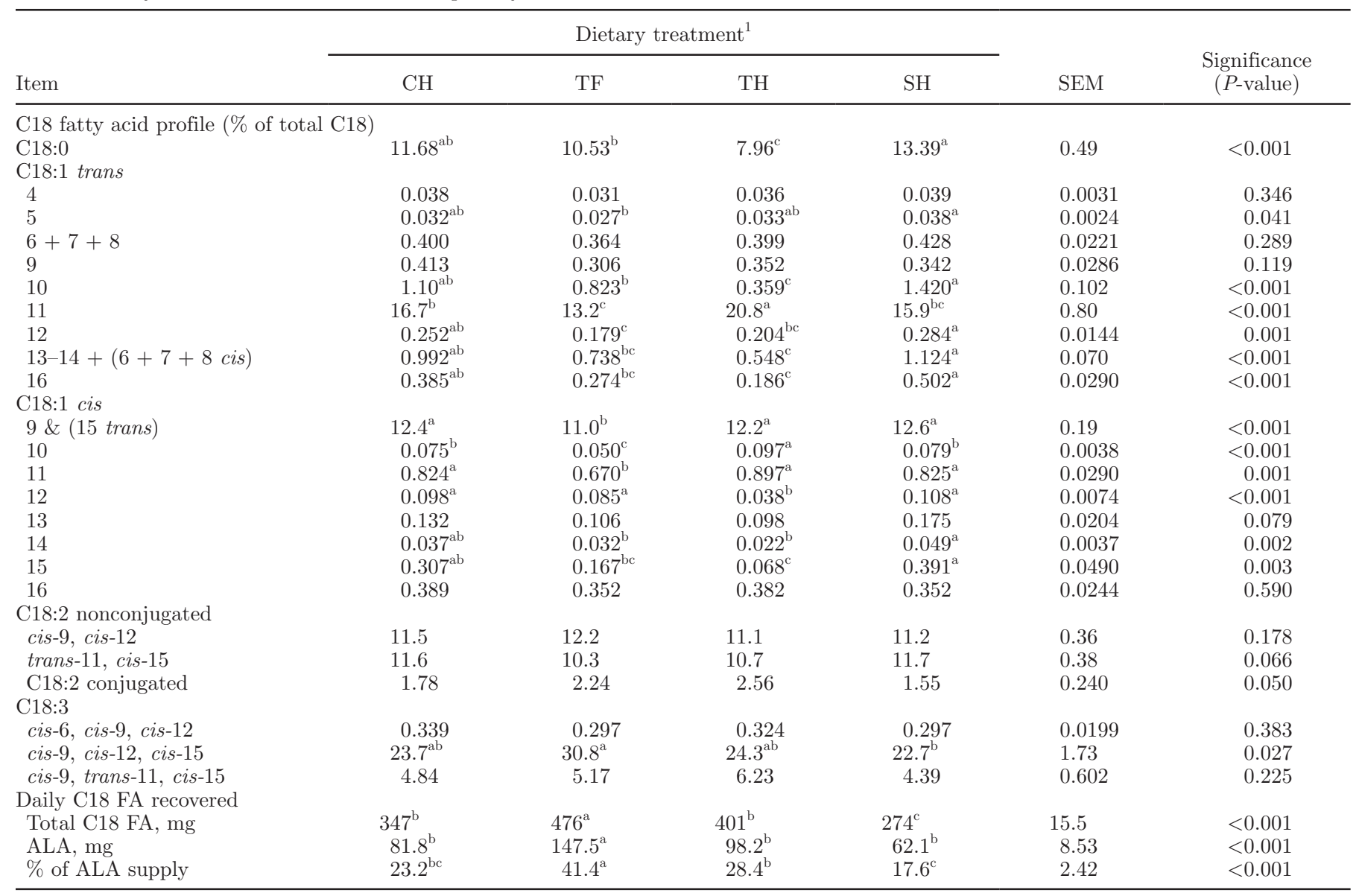

${ }^{\mathrm{a}-\mathrm{c}}$ Mean values within the same row sharing no common superscript are significantly different $(P<0.05)$.

${ }^{1} \mathrm{CH}=$ control; $\mathrm{TF}=$ tannin-containing forage (sainfoin); $\mathrm{TH}=$ tannin extract; and $\mathrm{SH}=$ saponin extract.

increase in bacterial counts by a factor of 2.6 relative to the control). The latter was most probably the consequence of the suppression of the protozoa that are important predators of bacteria. Reported effects of $\mathrm{CT}$ on protozoal counts in literature are quite variable. Makkar et al. (1995), for instance, noted that at increased bacterial counts, quebracho tannins decreased the number of both entodiniomorph and holotrich protozoa, whereby the latter appeared to have an even greater sensitivity to tannins. Carulla et al. (2005), feeding the Acacia mearnsii extract to sheep, also noted a decline of the holotrichs, but total protozoal counts increased, allowing bacterial counts to increase only to a very small extent. Even though total bacterial num-

Table 5. Apparent biohydrogenation $\left(\%\right.$ of supply $\left.{ }^{1}\right)$ of unsaturated C18 fatty acids (averages of d 6 to 10)

\begin{tabular}{lcccccc}
\hline & \multicolumn{5}{c}{ Dietary treatment ${ }^{2}$} & \\
\cline { 2 - 5 } Item & $\mathrm{CH}$ & $\mathrm{TF}$ & $\mathrm{TH}$ & $\mathrm{SH}$ & $\mathrm{SEM}$ & $\begin{array}{c}\text { Significance } \\
(P \text {-value })\end{array}$ \\
\hline $\mathrm{C} 18: 3 \mathrm{n}-3$ & $67.8^{\mathrm{a}}$ & $54.1^{\mathrm{b}}$ & $65.5^{\mathrm{a}}$ & $69.0^{\mathrm{a}}$ & 2.36 & 0.003 \\
C18:2n-6 & $47.6^{\mathrm{a}}$ & $37.7^{\mathrm{b}}$ & $46.1^{\mathrm{a}}$ & $49.4^{\mathrm{a}}$ & 1.83 & 0.005 \\
C18:1n-9 & 17.0 & 21.5 & 13.9 & 16.7 & 1.84 & 0.105 \\
Total unsaturated C18 & $56.5^{\mathrm{a}}$ & $46.2^{\mathrm{b}}$ & $54.4^{\mathrm{ab}}$ & $57.5^{\mathrm{a}}$ & 2.05 & 0.009 \\
\hline
\end{tabular}

${ }^{\mathrm{a}, \mathrm{b}}$ Mean values within the same row sharing no common superscript are significantly different $(P<0.05)$.

${ }^{1}$ Estimated from disappearance and after adjusting intake to fermenter-specific recovery rates of total fatty acids.

${ }^{2} \mathrm{CH}=$ control; $\mathrm{TF}=$ tannin-containing plant; $\mathrm{TH}=$ tannin extract; and $\mathrm{SH}=$ saponin extract. 


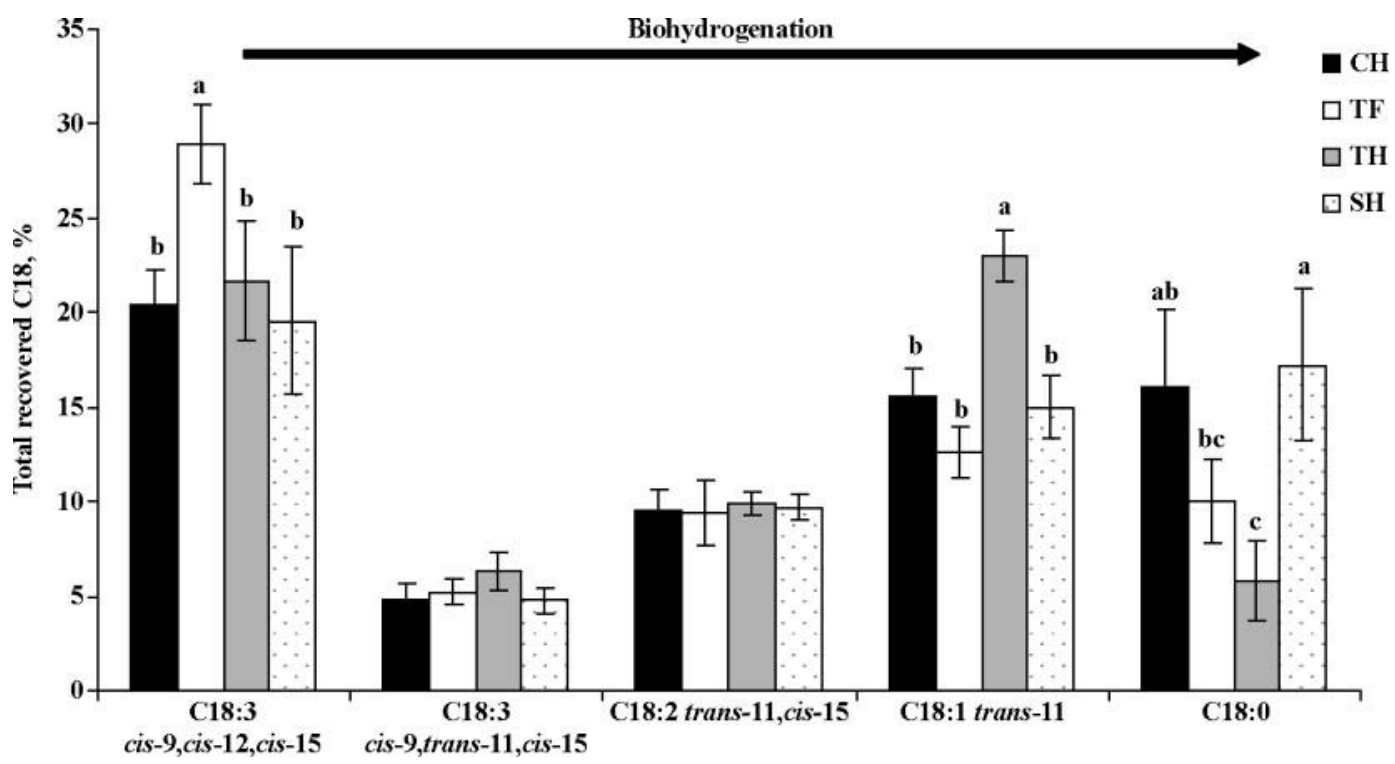

Figure 1. Effect of dietary treatments on the share of $\alpha$-linolenic acid as well as intermediates and end products of biohydrogenation made up from totally recovered $\mathrm{C} 18$ fatty acids. $\mathrm{CH}=$ control with grass-clover hay only; $\mathrm{TF}=$ sainfoin $($ Onobrychis viciifolia); $\mathrm{TH}=$ grass-clover hay plus CT-rich extract from Acacia mearnsii; and $\mathrm{SH}=$ grass-clover hay plus saponin-rich extract from Yucca schidigera ${ }^{\mathrm{a}-\mathrm{c}}$ Bars with different letters differ $(P<0.05)$.

bers may increase with the use of $\mathrm{CT}$, a shift among bacterial species might occur. Addition of sainfoin CT reduced growth and protease activity in Butyrivibrio fibrisolvens and Streptococcus bovis in the study of Jones et al. (1994), whereas strains of Prevotella ruminicola and Ruminobacter amylophilus were found to tolerate $\mathrm{CT}(<600 \mu \mathrm{g} / \mathrm{mL})$ originating from sainfoin leaves.

Consistent with the effects on microbial counts, TH was also much more effective in modifying ruminal fermentation traits than TF. Similar changes in the VFA profile (more propionate, less acetate and butyrate; also noted for group TF), as found in the present study, were reported from other studies adding CT (e.g., Carulla et al., 2005). With both CT treatments, decreases in nutrient degradation, especially $\mathrm{CP}, \mathrm{NDF}$, and ether extract, were found that were even more pronounced with sainfoin. It is, however, likely that the latter was an effect of the forage species characteristic involved (sainfoin vs. grass-clover mixture) and less so of CT. Although tannin structures are chemically very diverse, they all have protein binding properties (Terrill et al., 1992). This was also shown in previous reports that have identified the reduction of $\mathrm{CP}$ degradation as the predominant CT effect (Carulla et al., 2005; Tiemann et al., 2008), resulting in reduced ruminal ammonia concentration as described for Acacia mearnsii CT (Carulla et al., 2005). In agreement with a previous in vivo study (Carulla et al., 2005), methane emission in this study was suppressed by supplementing Acacia mearnsii $\mathrm{CT}$, whereas no such effect was found with sainfoin. Intact $\mathrm{CT}$ plants were shown, nevertheless, to reduce methane emissions (e.g., $-15 \%$ with Lotus corniculatus; Turner et al., 2005). Two mechanisms may explain the methane suppressing effect of the TH diet, the reduction of protozoa and therewith the associated methanogens and the lower fiber degradation, which might have limited hydrogen supply. Overall the Acacia mearnsii CT extract proved to be more effective than sainfoin even when the same amount of CT had been supplied. However, the more pronounced decrease in ruminal nutrient degradation with sainfoin was likely an effect of the property of the forage species involved (sainfoin vs. grass-clover mixture) and only partly affected by the sainfoin CT.

Previous studies showed the detrimental effect of saponins on protozoal counts (e.g., Santoso et al., 2007), whereas others found, under certain conditions, even increased numbers (e.g., Hess et al., 2003). In the present study, an enhanced protozoal growth was found with yucca saponins. It may be that this type of saponin is less efficient than others because also Eryavuz and Dehority (2004) found no suppressive effect on protozoal counts when feeding up to $20 \mathrm{~g}$ of yucca saponins/head/d to sheep for 3 wk. However, Wang et al. (2000) emphasized that cellulolytic bacteria are more susceptible to saponins than amylolytic bacteria. Additionally, saponins also selectively enhance the growth of individual bacterial species (Wallace et al., 1994) such as Prevotella ruminicola but depress the growth of Butyrivibrio fibrisolvens. But again, feeding 
5 to $20 \mathrm{~g}$ per d of yucca extract to sheep had no effect on ruminal cellulolytic and total bacteria concentrations (Eryavuz and Dehority, 2004). Similarly to its inefficiency in modifying ruminal microbial counts, the yucca extract remained without major effect on any of the ruminal fermentation traits in the present study. Wina et al. (2005) reviewed that out of 51 reports, 14 showed no effect and 17 showed a negative effect of saponins on ruminal ammonia concentration, whereby the extent of ruminal ammonia reduction due to the addition of Yucca schidigera was not consistent. Most of these reductions are to be explained with a saponindependent decrease of ruminal protozoa with less bacteria predation and therefore less ammonia formation results. This was also not the case in the present in vitro study. Wang et al. (2000) observed that effects of yucca saponins were highly diet-dependent because they for instance enhanced in vitro the fermentation of barley grain but not alfalfa hay. In addition, saponin type, origin, dose, and even the preparation process of the saponins might play a role in its activity.

\section{Effects of CT and Saponins on Ruminal Biohydrogenation of ALA}

The predominant C18 FA in the experimental diets was ALA originating from linseed oil and the forages. In the present study, there were 2 major modifications in ALA biohydrogenation caused by distinct diets, (i) the lesser level of ALA disappearance with the sainfoin diet (TF) and (ii) the increase in the penultimate product at cost of the expected end product with the tannin extract (diet TH). Consistent with the lack of effects of the saponin supplementation in ruminal fermentation, diet SE also proved to be inefficient in modifying the process of ALA biohydrogenation.

The C18 FA detected in effluents and feed residues (making up about $80 \%$ of total FA analyzed; data not shown) consisted of various cis- and trans-isomers of trienoic, dienoic, and monoenoic acids and stearic acid, the end product of biohydrogenation. There is a cascade of FA formation during ALA biohydrogenation. In detail, cis-9, trans-11, cis-15 C18:3 and trans-11, cis-15 C18:2 represented the respective predominant trienoic and dienoic acid intermediates of ALA biohydrogenation. The further steps of ALA biohydrogenation produce a wide range of different trans-octadecenoic acid isomers in the rumen (cf. Griinari and Bauman, 1999), of which, however, trans-11 C18:1 is the major isomer (Troegeler-Meynadier et al., 2006). This typical distribution of trans-C18:1 isomers appeared also in the present study.

The trans-11 C18:1 isomer is of particularly high importance as it serves as a precursor for cis-9, trans-11
CLA derived by the $\Delta^{9}$-desaturase activity in the mammary gland (Griinari and Bauman, 1999). Thus, it is an important result of the recent experiment that the treatment with the tannin extract leads to a potent and significant increase of trans-11 C18:1 (all other C18:1 FA were, at lesser levels, increased too). The accumulation of trans-11 C18:1 with diet TH can be considered as a genuine effect of a plant secondary constituent. Trans-11 C18:1 was the major product of biohydrogenation with diet $\mathrm{TH}$, whereas this was stearic acid in all other treatments. By contrast, the proportions of the trienoic and dienoic acid derivatives had not been affected by any of the treatments. This clearly showed that the CT extract inhibited only the last step of biohydrogenation, the reduction of trans-11 C18:1 to stearic acid.

Kemp and Lander (1984) classified bacteria involved in biohydrogenation into 2 groups based on the reaction and end products of biohydrogenation. Accordingly, group A bacteria, Ruminococcus albus and Butyrivibrio sp., are able to hydrogenate linoleic acid and ALA, with trans-11 C18:1 being their major end product. Group B bacteria, Fusocillus babrahamensis, Fusocillus sp. [later identified to Clostridium proteoclasticum, quoted by Durmic et al. (2007)], and an unnamed gram-negative $\operatorname{rod}(\mathrm{R} 8 / 5)$, are able to utilize trans-11 C18:1 as one of the main substrates to form stearic acid as the end product. According to Harfoot and Hazlewood (1997), species of ruminal bacteria catalyzing biohydrogenation were more frequently found in group $\mathrm{A}$, whereas only 3 isolates of group B are known. Only group B bacteria are able to hydrogenate oleic to stearic acid; this could explain why oleic acid suffered less from biohydrogenation than the other C18 FA. Additionally, the C18:1 reduction rate appears to be the limiting step of the complete biohydrogenation because fewer bacterial species (group B) are able to do this (quoted in Griinari and Bauman, 1999). Durmic et al. (2007) showed that an extract deriving from Acacia mearnsii has a selective inhibitory effect on Clostridium proteoclasticum P18 but not on Butyrivibrio fibrisolvens JW11. This supports our findings of an accumulation of trans-11 C18:1 with diet TH. Changes in ruminal environment, including $\mathrm{pH}$, and dietary factors such as fiber type and PUFA concentration, or even the use of ionophores appear to influence the formation of trans-C18:1 and CLA isomers (e.g., Li and Meng, 2006; Troegeler-Meynadier et al., 2006). Low $\mathrm{pH}$ was found to inhibit isomerization and the second reduction of linoleic acid, leading to an accumulation of trans-11 C18:1 (Troegeler-Meynadier et al., 2006). Because this was not the case in the present experiment, other changes in ruminal microbes and environment occurring with $\mathrm{TH}$ could have acted indirectly. Concerning sainfoin, this plant was shown to 
affect specific ruminal bacteria (Jones et al., 1994), but these species were either unimportant for biohydrogenation or they remained unaffected in the present study.

Based on the finding of a simultaneous disappearance of part of the ciliate protozoa and occurrence of incomplete biohydrogenation (at its terminal step) of polyunsaturated FA, Boeckaert et al. (2007) concluded that ciliates, their associated bacteria, or both might be involved in biohydrogenation. This would be consistent with the observed decrease in protozoal counts and incomplete biohydrogenation with the CT extract in the present study. In addition, in the long-term in vivo study of Yáñez-Ruiz et al. (2007) abomasum contents of protozoa-free lambs contained greater concentrations of vaccenic acid than faunated lambs, but there was no difference in rumenic acid and stearic acid concentrations. Further studies have to show whether the effect of the CT extract was thus mediated via its effect on ruminal protozoa, being either involved directly in biohydrogenation or via attached (group B) bacteria, or resulted from some more direct mechanisms. Finally, a limited hydrogen supply could have been another factor responsible for the reduced extent of biohydrogenation with the $\mathrm{CT}$ extract. In the present study a trend toward less free hydrogen was measured, which is consistent with the depression in protozoa as major hydrogen producers. Turner et al. (2005) suggested that the competition between methanogenesis and biohydrogenation for hydrogen could explain the CT effect on biohydrogenation. The low methane level found in the present study with $\mathrm{TH}$ actually indicates that obviously both ways of hydrogen utilization suffered from this shortage.

The strikingly less ALA degradation by biohydrogenation found with the sainfoin diet (TF) most likely was an indirect effect of the clearly lower ruminal nutrient degradability of sainfoin compared with the grass-clover mixture. The fact that ALA recovery was increased in the feed residues and not in the effluent and, further, that not only ALA but also total C18 FA recovery was significantly increased in the feed residues of diet $\mathrm{TF}$ show that these lipids generally remained in the structure components of the forage. Therefore, it can be assumed that the lipids present in sainfoin were less accessible to the microbes. Further, an indirect effect of a low degradability on the biohydrogenation rate of lipids accessible to microbes was described by Li and Meng (2006). These researchers observed that the use of a cell wall component extract from wheat straw, representing lignified fiber, caused a lower degree of biohydrogenation of linoleic acid from supplemented soybean oil compared with using digestible fiber (soybean hull extract). These effects could even have overruled the expected effects of the intrinsic $\mathrm{CT}$ in sainfoin. It has to be assumed that the extra ALA escaping the rumen with such forage residues is not fully digestible in the lower gut, and so would rather be lost than transferred to animal source foods. However, it has to be considered whether the increased ALA concentrations in milk fat found in cows grazing biodiverse pastures (Leiber et al., 2005) are caused by a low digestibility of such swards (Leiber et al., 2006). The assumption of CT being the reason for the elevated milk fat ALA (Leiber et al., 2005; Turner et al., 2005), however, could not be confirmed by the present study, other than the role of CT for enhancing milk fat CLA, which appears likely in the case of elevated trans-11 C18:1 with diet TH.

\section{CONCLUSIONS}

The diet based on the CT extract from Acacia mearnsii was found to be the only one containing secondary plant compounds effective in modifying ruminal biohydrogenation. There was a distinct point of action, namely the (partial) inhibition of the terminal step, thus leading to an accumulation of trans-11 C18:1. Conversion of this FA to cis-9, trans-11 C18:2 by the $\Delta^{9}$ desaturase in mammary gland and body tissue has been reported to be a major source of cis-9, trans-11 C18:2 in ruminant source foods rather than the direct result of absorption of cis-9, trans-11 C18:2 escaping from the rumen (Griinari and Bauman, 1999). Considering this, Acacia mearnsii $\mathrm{CT}$, though not reducing ALA losses via biohydrogenation, could be beneficial from a human health point of view. Further studies are necessary to investigate ruminal biohydrogenation with varying CT doses and types as well as to identify the bacterial species that are capable to carry out the terminal step of biohydrogenation. Moreover, investigating CTtolerant bacterial species, whereof some already have been isolated (Jones et al., 1994), and their involvement in biohydrogenation and their interrelation with other species involved in biohydrogenation, could be helpful in understanding the conditions and mechanisms of CT effects on ruminal biohydrogenation.

\section{REFERENCES}

Aldai, N., B. E. Murray, A. I. Nájera, D. J. Troy, and K. Osoro. 2005. Review: Derivatization of fatty acids and its application for conjugated linoleic acid studies in ruminant meat lipids. J. Sci. Food Agric. 85:1073-1083.

AOAC. 1997. Official Methods of Analysis. Assoc. Off. Anal. Chem., Arlington, VA.

Boeckaert, C., V. Fievez, D. Van Hecke, W. Verstraete, and N. Boon. 2007. Changes in rumen biohydrogenation intermediates and ciliate protozoa diversity after algae supplementation to dairy cattle. Eur. J. Lipid Sci. Technol. 109:767-777.

Carulla, J. E., M. Kreuzer, A. Machmüller, and H. D. Hess. 2005. Supplementation of Acacia mearnsii tannins decreases methanogenesis and urinary nitrogen in forage-fed sheep. Aust. J. Agric. Res. 56:961-970. 
Durmic, Z., C. S. McSweeney, G. W. Kemp, P. Hutton, R. J. Wallace, and P. E. Vercoe. 2007. Australian plants with potential to inhibit bacteria and processes involved in ruminal biohydrogenation of fatty acids. Anim. Feed Sci. Technol. doi:10.1016/j. anifeedsci.2007.05.052

Ehrlich, G. G., D. F. Goerlitz, J. H. Bourell, G. V. Eisen, and E. M. Godsy. 1981. Liquid chromatographic procedure for fermentation product analysis in the identification of anaerobic bacteria. Appl. Environ. Microbiol. 42:878-886.

Eryavuz, A., and B. A. Dehority. 2004. Effect of Yucca schidigera extract on the concentration of rumen microorganisms in sheep. Anim. Feed Sci. Technol. 117:215-222.

Fievez, V., B. Vlaeminck, T. Jenkins, F. Enjalbert, and M. Doreau. 2007. Assessing rumen biohydrogenation and its manipulation in vivo, in vitro and in situ. Eur. J. Lipid Sci. Technol. 109:740756.

Griinari, J. M., and D. E. Bauman. 1999. Biosynthesis of conjugated linoleic acid and its incorporation into meat and milk in ruminants. Pages 180-200 in Advances in Conjugated Linoleic Acid Research. Vol. 1. M. P. Yurawecz, M. M. Mossoba, J. K. G. Kramer, M. W. Pariza, and G. J. Nelson, ed. AOCS Press, Champaign, IL.

Harfoot, C. G., and G. P. Hazlewood. 1997. Lipid metabolism in the rumen. Pages 382-426 in The Rumen Microbial Ecosystem. 2nd ed. P. N. Hobson and C. S. Stewart, ed. Blackie Academic \& Professional, London, UK.

Hess, H. D., M. Kreuzer, T. E. Díaz, C. E. Lascano, J. E. Carulla, C. R. Soliva, and A. Machmüller. 2003. Saponin rich tropical fruits affect fermentation and methanogenesis in faunated and defaunated rumen fluid. Anim. Feed Sci. Technol. 109:79-94.

Jones, G. A., T. A. McAllister, K.-J. Cheng, and A. D. Muir. 1994. Effect of sainfoin (Onobrychris viciifolia Scop) condensed tannins on growth and proteolysis by 4 strains of rumen bacteria. Appl. Environ. Microbiol. 60:1374-1378.

Kemp, P., and D. J. Lander. 1984. Hydrogenation in vitro of $\alpha$-linolenic acid to stearic acid by mixed cultures of pure strains of rumen bacteria. J. Gen. Microbiol. 130:527-533.

Kramer, J. K. G., and J. Zhou. 2001. Conjugated linoleic acid and octadecanoic acids: Extraction and isolation of lipids. Eur. J. Lipid Sci. Technol. 103:594-632.

Leiber, F., M. Kreuzer, H. Leuenberger, and H.-R. Wettstein. 2006. Contribution of diet type and pasture conditions to the influence of high altitude grazing on intake, performance and composition and renneting properties of the milk of cows. Anim. Res. 55:37-53.

Leiber, F., M. Kreuzer, D. Nigg, H.-R. Wettstein, and M. R. L. Scheeder. 2005. A study on the causes for the elevated n-3 fatty acids in cow's milk of alpine origin. Lipids 40:191-202.

Li, Y., and Q. Meng. 2006. Effect of different types of fibre supplemented with sunflower oil on ruminal fermentation and production of conjugated linoleic acids in vitro. Arch. Anim. Nutr. 60:402-411.

Makkar, H. P. S., K. Becker, H. J. Abel, and C. Szegletti. 1995. Degradation of condensed tannins by rumen microbes exposed to quebracho tannins (QT) in rumen simulation technique (RUSITEC) and effects of QT on fermentative processes in the RUSITEC. J. Sci. Food Agric. 69:495-500.

Martin, S. A., and T. C. Jenkins. 2002. Factors affecting conjugated linoleic acid and trans- $\mathrm{C}_{18: 1}$ fatty acid production by mixed ruminal bacteria. J. Anim. Sci. 80:3347-3352.

Robbins, C. T., S. Mole, A. E. Hagerman, and T. A. Hanley. 1987. Role of tannins in defending plants against ruminants: Reduction in dry matter digestion. Ecology 68:1606-1615.

Santoso, B., A. Kilmaskossu, and P. Sambodo. 2007. Effects of saponin from Biophytum petersianum Klotzsch on ruminal fermentation, microbial protein synthesis and nitrogen utilization in goats. Anim. Feed Sci. Technol. 137:58-68.

Smedes, F. 1999. Determination of total lipid using non-chlorinated solvents. Analyst (Lond.) 124:1711-1718.

Soliva, C. R., and H. D. Hess. 2007. Measuring methane emission of ruminants by in vitro and in vivo techniques. Pages $15-31$ in Measuring Methane Production from Ruminants. H. P. S. Makkar and P. E. Vercoe, ed. Springer, Dordrecht, the Netherlands.

Terrill, T. H., A. M. Rowan, G. B. Douglas, and T. N. Barry. 1992 Determination of extractable and bound condensed tannin concentrations in forage plants, protein-concentrate meals and cereal-grains. J. Sci. Food Agric. 58:321-329.

Tiemann, T. T., P. Avila, G. Ramízrez, C. E. Lascano, M. Kreuzer, and H. D. Hess. 2008. In vitro ruminal fermentation of tanniniferous tropical plants: Plant-specific tannin effects and counteracting efficiency of PEG. Anim. Feed Sci. Technol. doi:10.1016/ janifeedsci.2007.12.009.

Troegeler-Meynadier, A., L. Bret-Bennis, and F. Enjalbert. 2006. Rates and efficiencies of reactions of ruminal biohydrogenation of linoleic acid according to $\mathrm{pH}$ and polyunsaturated fatty acids concentrations. Reprod. Nutr. Dev. 26:713-724.

Turner, S.-A., G. C. Waghorn, S. L. Woodhard, and N. A. Thomson 2005. Condensed tannins in birdsfoot trefoil (Lotus corniculatus) affect the detailed composition of milk from dairy cows. Proc. N.Z. Soc. Anim. Prod. 65:283-289.

Wallace, R. J., L. Arthaud, and C. J. Newbold. 1994. Influence of Yucca schidigera extract on ruminal ammonia concentrations and ruminal microorganisms. Appl. Environ. Microbiol. 60:17621767.

Wang, Y., T. A. McAllister, L. J. Yanke, Z. J. Xu, P. R. Cheeke, and K.-J. Cheng. 2000. In vitro effects of steroidal saponins from Yucca schidigera extract on rumen microbial protein synthesis and ruminal fermentation. J. Sci. Food Agric. 80:2114-2122.

Wina, E., S. Muetzel, and K. Becker. 2005. The impact of saponins or saponin-containing plant materials on ruminant production- $\mathrm{A}$ review. J. Agric. Food Chem. 53:8093-8105.

Yáñez-Ruiz, D. R., S. Williams, and C. J. Newbold. 2007. The effect of absence of protozoa on rumen biohydrogenation and the fatty acid composition of lamb muscle. Br. J. Nutr. 97:938-948. 